DOI: 10.35340/2308-104X.2020.87-2-14

\section{ОРГАНІЗАЦІЯ УПРАВЛІННЯ ФУНКЦІОНАЛЬНОЮ ДІЯЛЬНІСТЮ ПІДПРИЕМСТВ МОРСЬКОГО ТРАНСПОРТУ}

\section{ORGANIZATION OF \\ MANAGEMENT OF FUNCTIONAL ACTIVITY OF MARITIME TRANSPORT ENTERPRISES}

\author{
OCHEREDCO O.,
}

Senior Lecturer of the Department of Management and Entrepreneurship on Maritime Transport, Azov Maritime Institute. National University, "Odesa Maritime Academy"

\author{
ОЧЕРЕДЬКО О. О., \\ старший викладач кафедри \\ «Менеджмент і підприсмництво \\ на морському транспорті», \\ Азовський морський інститут \\ Національного університету, \\ «Одеська морська академія»
}

У статті проаналізована організацію управління функціональною діяльністю підприємств морського транспорту. Існуючі проблеми та перспективи розвитку морегосподарського комплексу. На сучасному етапі $\epsilon$ необхідність підтримки та удосконалення механізмів державного регулювання діяльності підприємств морського транспорту.

Ключові слова: управління, функиіональна діяльність, підприємства морського транспорту.

В статье проанализирована сущность управления функичиональной деятельностью предприятий морского транспорта. Существующие проблемь и перспективы развития морехозяйственного комплекса. На современном этапе развития существует необходимость піддержки и усовершенствования механизмов государственного регулирования деятельности предприятий морского транспорта.

Ключевые слова: управление, функииональная деятельность, предприятия морского транспорта.

In this article I analysed the organization of management of functional activity of maritime transport enterprises, as well as existing problems and prospects of the maritime economic complex development. At the present stage, there is a need to support and improve the mechanisms of maritime transport enterprises regulation by the government.

Keywords: management, functional activity, maritime transport enterprises.

Постановка проблеми. Управління ефективною діяльністю підприємств морського транспорту підприємств засноване на обліку принципових положень і закономірностей оптимізації функціональної діяльності в системі суперечливих ринкових обмежень. Проблема ефективного використання ресурсів виникає з формуванням конкурентних 
технологій і альтернативного їх використання в умовах обмеженості ресурсів і попиту.

Аналіз останніх досліджень $i$ публікащій. Проблеми організації управління функціональною діяльність морського транспорту я в торгівельному судноплавстві приділяється увага в ряді робіт, серед яких слід виділити праці: В. М. Гейця, М. Т. Примачова, В. Г Коби, С. В. Ільченко, I. А. Голубкової, О. М. Кібік, О. А. Липинської, М. В.Макаренко, В. В. Жихарєвої, О. Ф. Балацького, Проте повною мірою не розкрито взаємозв'язок національних інтересів і адміністрування за критеріями антикризового управління.

Головною метою цієї роботи $є$ організація ефективного функціонування діяльності морських підприємств та посилення вимог до менеджменту за принципами зовнішнього управління. Це особливо позначається на виборі стратегії і задач позиціювання України на ринку морського транспорту.

Виклад основного матеріалу дослідження. Поступово в історичному плані формувалася методика оцінки ефективного розвитку та залучення інвестиційних коштів. При цьому слід розрізняти рівні і цілі розрахунку ефективності [1]. На макроекономічному рівні головними показниками позиціонування, що забезпечують ефективність функціонування, залишаються управління продуктивністю праці, оптимальністю ВВП на душу населення, віддачею капітальних вкладень, раціональністю енергоспоживання, a на рівні окремих галузей i підприємств продуктивність праці, середні витрати, норма прибутку і віддача капіталу.

У будь-якому випадку наукові основи управління ефективністю повинні враховувати вдосконалення методів управління морського транспорту. Вплив капітальних вкладень на результати роботи морського транспорту протягом тривалого періоду часу пред'являє особливу вимогу до методів планування ефективності. Необхідність формування максимальних результатів при обмеженому бюджеті обумовлює принцип мінімізації витрат [1, с. 76].

У методах управління ефективністю не розкритий ряд принципових положень, що відображають здатність негативного впливу ринкового середовища. Тому загальну ефективність господарювання можна розрахувати за обмеженими умовами. При цьому враховуються тільки результати виробництва, і часто ігнорується необхідність відображення сприймаємої цінності ринкового позиціювання морського транспорту. При визначенні абсолютної економічної ефективності окремих проектів 
шляхом зіставлення ефекту з сукупністю ресурсів, що використовуються при виробництві, фактично ігнорується альтернативна стратегія застосування обмежених ресурсів. Принцип порівняння результату ресурсів відображає сутність категорії економічної ефективності і īi критерії. При цьому в якості детермінанта ефективності економічного розвитку виступають інвестиційні ресурси [2].

Стрімке зростання обсягів морських перевезень в період становлення глобальних економічних відносин (1996-2007 рр.) суттєво вплинуло на характер формування капітальної вартості флоту i торгових портів i збалансованості людського капіталу. При високих темпах розвитку морської торгівлі зростали витрати на використання і доставку природних ресурсів і витрати по екології світового океану. Саме в цьому процесі формується особлива регуляторна роль управління підприємств морського транспорту з боку глобальних організацій.

Цільовий підхід до оптимізації параметрів економічного розвитку та забезпечення конкурентних умов роботи морського транспорту зумовлює актуальність вдосконалення процесів організації управління.

Одночасно зростає роль енергоозброєності праці, що забезпечує економію робочого часу, таким чином і зростання його продуктивності. У будь-якому випадку ефективність розвитку морського транспорту необхідно засновувати на зниженні ресурсоємності функціональної діяльності. Результати виробництва залежать від чотирьох груп факторів: стабільності та ритмічності завантаження виробничого потенціалу, оптимальності взаємодії підрозділів виробничої інфраструктури на принципах логістики. У будь-якому з них в тій чи іншій мірі відбивається принцип посилення регуляторного управління за системою стандартів.

Щоб уникнути практики, заснованої на концентрації уваги власників капіталу на забезпечення його пріоритетної ефективності, посилюється управління 3 боку глобальних морських організацій за критеріями соціально-економічної справедливості [3].

Управління функціональною діяльністю підприємств морського транспорту найчастіше орієнтовано на оцінку інвестиційної та виробничої діяльності. Особливу роль відіграє принцип обгрунтування ефективності інвестиційних проектів. Спочатку повинна визначатися ефективність заходів щодо розвитку базового стану. У структурі функціональної діяльності принциповим стає оцінка ефективність кінцевих результатів за умовами і факторам зовнішнього і внутрішнього порядку. 
До головних вимог комплексу управління відноситься системність обліку віддачі виробничого потенціалу. У формуванні ефективності виділяється рівень раціональності витрат праці і якості технічних засобів. судноплавний комплекс повинен орієнтуватися на нормальне використання потужностей, що забезпечує своєчасність відтворення потенціалу.

Для оптимізації управління підприємницькими результатами підприємств морського транспорту або портів найважливішою проблемою стає вдосконалення обліку показників на базі диверсифікації цілей розвитку і функціонування [4]. У системі управління за характером відображення ефективності слід розрізняти дві групи показників: результативні - загальний розмір чистого доходу і його відношення на одиницю ресурсів; підприємницькі - співвідношення результатів і витрат. Для першої групи кредо достовірності - норматив або стандарти. Для другої - максимізація фондоутворючих результатів.

Слід враховувати розширення сфери конвенційного регулювання безпеки мореплавання на основі обмежень з боку IMO, що і коригує чисті комерційні результати і витрати. Такі рішення періодично обумовлюють в певній мірі зростання вартості флоту. У зв'язку 3 цим процесом формується зниження придатності діючих суден для ефективного використання в певних сегментах морського транспорту. Коефіцієнт придатності відображає параметри можливої подальшої віддачі основного капіталу за певних стандартах і обмеженнях. У кінцевому рахунку, ринкова вартість суден визначається методом аналогій, капіталізації i методом витрат [5].

У зв'язку із зазначеним в торгівельному судноплавстві значимість людських навичок (soft skills), шляхів їх становлення і розвитку різко зросла. У більшості судноплавних компаній надається велике значення накопиченню людського капіталу, як найціннішого з усіх видів стратегій, що забезпечують використання капітальних активів. Одним із способів накопичення людського капіталу $є$ інвестування в людину. Проблема підвищення ефективності використання продуктивних сил, що реалізуються в сучасних умовах у формі людського капіталу, висувається в розряд першочергових завдань у структурі соціально-економічних досліджень. Це передбачає проведення спеціальних досліджень даної проблеми, що і знаходить відображення в інституційних рішеннях IMO, поруч із власне жорстким управлінням на основі Манільських поправок [6]. 
Незважаючи на підвищення техніко-економічного рівня суден 3 метою зниження систематичних ризиків зростає роль виникнення загроз, що зумовлюються агресивністю окремих соціальних груп. Тому виділяються проблеми, адекватні реакції щодо зниження ризику для життя моряків і збитку операторів світової торгівлі і судноплавства.

3 метою стабілізації ринок морської торгівлі в умовах складного процесу диференціації позиціонування окремих судноплавних компаній посилюється вплив IMO на основні принципи управління. Останнє повинно особливо враховуватися механізмом збалансованості різносистемних факторів розвитку море господарського комплексу.

Розвиток ринкових відносин та лібералізація національної зовнішньої торгівлі України за принципами Світова організація торгівлі (WTO) фактично привели до посилення конкуренції на внутрішньому ринку. За такими умовами, враховуючи найвищий рівень енергоємності економіки серед європейських країн, вітчизняні підприємства змушені шукати нові шляхи підвищення своєї конкурентоспроможності та ефективності.

Цілком обгрунтованим фундаментом ефективного менеджменту та успішного розвитку підприємництв на морському транспорті вважається організаційна структура компанії. Однак у більшості світових судноплавних компаніях існуюча організаційна структура склалася стихійно, а система управління заснована на попередньому досвіді i світогляді менеджера і не є оптимальною. До того ж, до останнього часу методи побудови системи управління ефективним функціонуванням підприємств морського траснпорту характеризувалися надмірною орієнтацією на нормативний характер. Це зумовлює недостатнє різноманіття, що призводило до механічного перенесення організаційних форм, що застосовувалися в минулому, в сучасні умови. В період глобалізації забезпечити підприємству ефективне функціонування та конкурентні переваги може лише ефективна система управління його економічною діяльністю 3 урахуванням принципів адміністрування за критеріями безпеки.

Склад управлінських робіт, необхідних для реалізації тих чи інших функцій управління, і порядок їх виконання визначають технологію управління. Можна сказати що, технологія управління - це система інформаційних, логічних, обчислювальних, організаційних операцій, що виконуються керівниками, фахівцями та технічними виконавцями [7]. 
Висновки $і$ перспективи подальщих досліджень. У кожному разі морегосподарський комплекс $\epsilon$ галуззю, що заслуговує державної підтримки, завдяки своєму потенціалу до виживання, крім інших факторів. Це особливо необхідно в перехідний період, коли матеріально-технічна база морського транспорту знаходиться в дуже невігідному положенні, а ринкові механізми ще не діють повною мірою розкрити весь потенціал підприємствам морського транспоту. Система організації управління, що побудована тепер в Україні повною мірою задовольняє світовим тенденціям - лібералізація, децентралізація, комерціалізація та активна участь приватного сектора. Нове законодавство остаточно розмежовує функції господарської діяльності та її регулювання, при цьому створена структура - Адміністрація морських портів України. Але підвищити ефективність організації системи управління підприємствами можна за рахунок оптимізації кількості портових адміністрацій у відповідності до їх географічного розподілу та спеціалізації, що дозволить не тільки зменшити витрати на утримання адміністративно-управлінського та технічного персоналу, а й підвищити якість процесу прийняття рішень за рахунок кращого використання обмеженого кадрового ресурсу, комплексного та системного підходу до вирішення аналогічних проблем морських портових комплексів.

\section{Лimepamyра:}

1. Horvath \& Partners; Внедрение сбалансированной системы показателей / пер. с нем. В. Толкача, С. Данишевич, М. Гавриша. Москва: Альпина Бизнес Букс, 2005. 478 с.

2. Манільські поправки до додатка до Міжнародної конвенції про підготовку і дипломування моряків та несення вахти 1978 року: Поправки, Резолюція, Правила від 25.06.2010. Офіиійний вісник Украйни. 2012. 24. Ст. 940.

3. Примачев Н. Т., Примачев А. Н. Принципы интеграции в торговом судоходстве: монографія. Одесса: Феникс, 2006. 360 с.

4. Примачев Н. Т., Бойко П. А., Примачева Н. Н. Экономические основы функционирования морского рынка транспортных услуг. Одесса: Автограф, 2004. 320c.

5. Review of Maritime Transport, 2007 Report by the UNCTAD secretariat. United Nations New York and Geneva: UN, 2007. 167 p

6. RS Platou report. Norvey: Oslo, Platou, 2010. 52 p. 
References:

1. Horvath \& Partners; Vnedrenye sbalansyrovannoj systemы pokazatelej / per. s nem. V. Tolkacha, S. Danyshevych, M. Ghavrysha. Moskva: Aljpyna Byznes Buks, 2005. $478 \mathrm{~s}$.

2. Maniljsjki popravky do dodatka do Mizhnarodnoji konvenciji pro pidghotovku i dyplomuvannja morjakiv ta nesennja vakhty 1978 roku: Popravky, Rezoljucija, Pravyla vid 25.06.2010. Oficijnyj visnyk Ukrajiny. 2012. 24. St. 940.

3. Primachev N. T., Primachev A. N. Printsipy integratsii v torgovom sudokhodstve: monografiya. Odessa: Feniks, 2006. 360 s.

4. Primachev N. T., Boyko P. A., Primacheva N. N. Ekonomicheskie osnovy funktsionirovaniya morskogo rynka transportnykh uslug. Odessa: Avtograf, 2004. 320s.

5. Review of Maritime Transport, 2007 Report by the UNCTAD secretariat. United Nations New York and Geneva: UN, 2007. 167 p

6. RS Platou report. Norvey: Oslo, Platou, 2010. 52 p.

In this article I analysed the organization of management of functional activity of maritime transport enterprises, as well as existing problems and prospects of the maritime economic complex development. At the present stage, there is a need to support and improve the mechanisms of maritime transport enterprises regulation by the government.

The main purpose of this work is to organize the effective functioning of the activities of maritime enterprises and to strengthen the requirements to management according to the principles of external management. This has a strong influence on the choice of strategy and tasks for positioning Ukraine in the maritime transport market.

In relation to the mentioned issue, the importance of soft skills, ways of their formation and development have increased dramatically. Most shipping companies pay the greatest attention to the accumulation of human capital, as the most valuable of all types of strategies that ensure the use of capital assets. One way to accumulate human capital is to invest in people. The problem of increasing the efficiency of the use of productive forces, which are implemented in the present conditions in the form of human capital, is being put in the category of priority tasks in the structure of socio-economic research. 
This involves conducting specific studies of the problem, which is reflected in IMO's institutional decisions, alongside rigid Manila-based governance.

In order to stabilize the maritime trade market in the conditions of complex process of differentiation of positioning of some shipping companies, the influence of IMO on the basic principles of management is increasing. These basic principles of management should be particularly taken into account by the mechanism of balance of the various systemic factors of the sea development complex.

In each case, the sea economic complex is an industry that deserves state support due to its potential for survival, among other factors. This is especially necessary in a transitional period when the logistics of maritime transport is in a very disadvantaged position and market mechanisms are not yet fully operational to unlock the full potential of maritime transport enterprises. 